
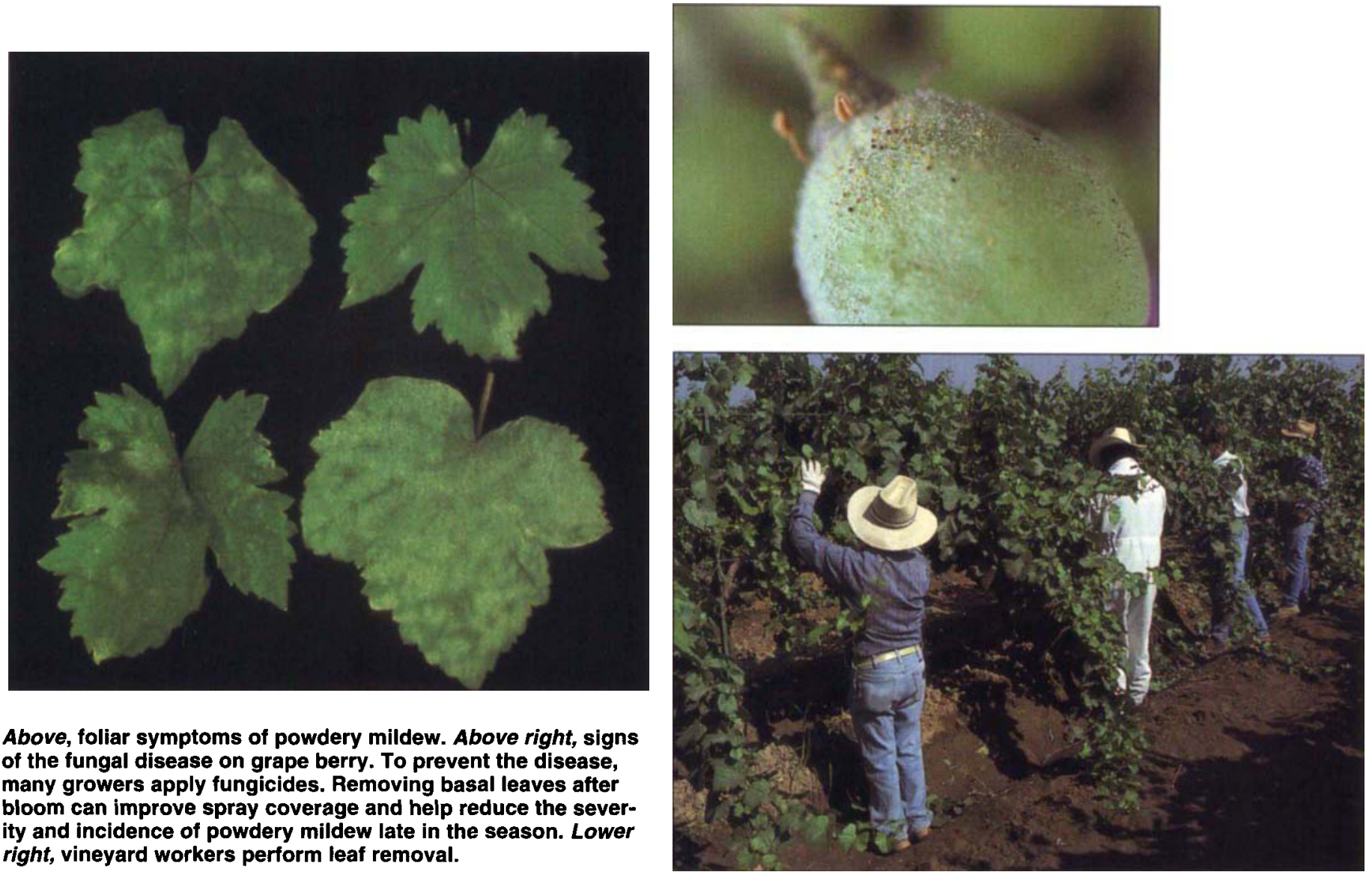

Above, foliar symptoms of powdery mildew. Above right, signs of the fungal disease on grape berry. To prevent the disease, many growers apply fungicides. Removing basal leaves after bloom can improve spray coverage and help reduce the severity and incidence of powdery mildew late in the season. Lower right, vineyard workers perform leaf removal.

\title{
Leaf removal improves fungicide control of powdery mildew in SJV grapes
}

\author{
James J. Stapleton a George M. Leavitt a Paul S. Verdegaal
}

\begin{abstract}
Basal leaf removal, which has been used to reduce damage from bunch rots and seasonal leafhopper infestations, was tested for its effects on powdery mildew in the San Joaquin Valley. Powdery mildew is one of the most damaging diseases of wine grapes in California. On-farm experiments showed that leaf removal reauced the disease in two of five experiments and facilitated improved spray coverage in grapevine fruiting zones. Leaf removal can improve the effectiveness of fungicide programs in reducing powdery mildew damage, but should not be relied upon alone to control the disease.
\end{abstract}

$\mathrm{P}$ owdery mildew, caused by the fungus Uncinula necator (Burr [Schw.]), is probably the most consistently damaging disease of wine grapes (Vitis vinifera L.) in California, occurring in every climatic growing region of the state. To prevent its occurrence, most growers regularly apply fungicides, including sulfur (dust, wettable sulfur, or calcium polysulfide [lime sulfur] formulations), and/or ergosterol biosynthesis inhibitors such as myclobutanil (Rally), triadimefon (Bayleton), or fenarimol (Rubigan).

In recent years, many California wine grape growers have adopted basal leaf removal as a means of canopy management to enhance the quality of premium varietals and provide non-chemical control of bunch rots and insect pests, including leafhoppers and the omnivorous leafroller (California Agriculture, March-April 1989; September-October 1990). In the coastal Napa Valley, leaf removal also has been used successfully to reduce damage due to powdery mildew. Grape-growing areas in California's coastal valleys are generally cooler and more humid than those in the central and desert valleys, which are further removed from the influence of the Pacific Ocean. In the coastal areas, the primary source of powdery mildew seems to consist mainly of ascospores from cleistothecia overwintering in vine bark, while in the hotter and drier interior areas, powdery mildew epidemics often develop from overwintered bud infections. 
Our objective was to determine if leaf removal would provide an economical way of controlling powdery mildew on grapevines in the San Joaquin Valley and whether it would reduce the amount of fungicides needed to prevent the disease. We also compared fungicide spray coverage inside grapevine canopies.

\section{On-farm experiments}

Basal leaf removal was tested in several on-farm experiments to determine its effect on powdery mildew, usable grape yield, and fungicide efficacy and coverage.

Five field experiments were conducted during 1989 to 1991 in commercial wine grape vineyards in the San Joaquin Valley. Three sites were located near Madera, in the central part of the valley, and two near Lodi, in the northern valley. Treatments in each experiment are summarized in table 1. Procedures were as follows:

Madera 1989. To evaluate the effects of leaf removal and fungicide spray programs on powdery mildew, we used a 2-by-2 factorially designed experiment plot. The test site was a bilateral, cordon-trained and spurpruned Carignane vineyard with rows oriented in a north-south direction. We evaluated four treatments: leaf removal from both sides of the vines with no subsequent fungicide applications; the grower's full spray program; leaf removal plus the full spray program; and a partial spray program. Tests were conducted on six replicates of 12 vines each. Powdery mildew was evaluated on July 12 and September 1 .

Lodi 1989. The experimental site was a head-trained, spur-pruned Carignane vineyard with an east-west orientation and a history of powdery mildew infection. Treatments were similar to those in Madera, but eight replicates of six vines were used per treatment. We removed basal leaves from vine canopies, leaving a thin layer on the southwest quadrant of each vine to protect against afternoon sun damage. Powdery mildew incidence and severity were evaluated on July 26, and again on October 5.

TABLE 1. Fungicide (active ingredient) and leaf removal treatment summary for field experiments

\begin{tabular}{|c|c|c|c|c|c|}
\hline \multirow[b]{2}{*}{ Location, year, treatment } & \multirow[b]{2}{*}{ Date } & \multicolumn{4}{|c|}{ Treatment } \\
\hline & & Leaf removal* & $\begin{array}{l}\text { Grower's } \\
\text { standard } \\
\text { practicet }\end{array}$ & $\begin{array}{c}\text { Leaf removal } \\
\text { +grower's } \\
\text { practice }\end{array}$ & Control \\
\hline \multicolumn{6}{|l|}{ Lodi 1989} \\
\hline Wettable sulfur (WS) (6.0 lb) & March 6 & $\mathrm{~F} \ddagger$ & $\mathrm{F}$ & $\mathrm{F}$ & $\mathrm{F}$ \\
\hline $\begin{array}{l}\text { Myclobutanil (MB) }(0.31 \mathrm{lb}) \text {; } \\
\text { WS }(1.5 \mathrm{lb})\end{array}$ & May 8 & $F$ & $\mathrm{~F}$ & $\mathrm{~F}$ & $\mathrm{~F}$ \\
\hline WS $(1.5 \mathrm{lb})$ & May 16 & $\mathrm{~F}$ & $\mathrm{~F}$ & $\mathrm{~F}$ & $\mathbf{F}$ \\
\hline MB (0.25 lb); WS (0.81 lb) & May 26 & 0 & $\mathrm{~F}$ & $\mathrm{~F}$ & 0 \\
\hline Leaf removal & June 8-9 & $\mathrm{x}$ & 0 & $x$ & 0 \\
\hline MB; WS & June 16 & 0 & $\mathrm{~F}$ & $\mathrm{~F}$ & 0 \\
\hline \multicolumn{6}{|l|}{ Madera 1989} \\
\hline Fenarimol (FM) $(0.20 \mathrm{lb})$ & May 1 & $\mathrm{~F}$ & $\mathrm{~F}$ & $\mathbf{F}$ & $\mathrm{F}$ \\
\hline FM $(0.25 \mathrm{lb}) ;$ WS (1.5 lb) & May 15 & $\mathrm{~F}$ & $\mathrm{~F}$ & $\mathrm{~F}$ & $\mathrm{~F}$ \\
\hline Leaf removal & May 24 & $\mathrm{x}$ & 0 & $\mathrm{x}$ & 0 \\
\hline FM $(0.38 \mathrm{lb})$; WS (1.5 lb) & May 30 & $\mathrm{~F}$ & $\mathrm{~F}$ & $\mathrm{~F}$ & $\mathrm{~F}$ \\
\hline $\mathrm{FM}(0.38 \mathrm{lb})$ & June 14 & 0 & $\mathrm{~F}$ & $\mathrm{~F}$ & 0 \\
\hline \multicolumn{6}{|l|}{ Lodi 1990} \\
\hline Calcium polysulfide (CP) (0.75 lb) & April 6 & $\mathrm{~F}$ & $\mathrm{~F}$ & $\mathrm{~F}$ & 0 \\
\hline Sulfur dust (SD) (15.0 Ib) & April 11 & $\mathrm{~F}$ & $\mathrm{~F}$ & $\mathrm{~F}$ & 0 \\
\hline MB (0.25 lb); WS & April 18 & $\mathrm{~F}$ & $\mathrm{~F}$ & $\mathrm{~F}$ & 0 \\
\hline SD & April 24 & $\mathrm{~F}$ & $\mathrm{~F}$ & $\mathrm{~F}$ & 0 \\
\hline SD & May 7 & 0 & $\mathrm{~F}$ & $\mathrm{~F}$ & 0 \\
\hline SD & May 18 & 0 & $\mathrm{~F}$ & $\mathrm{~F}$ & 0 \\
\hline MB; WS (5.0 lb); CP (0.38 lb) & May 24 & 0 & $\mathrm{~F}$ & $\mathrm{~F}$ & 0 \\
\hline SD & May 26 & 0 & $\mathrm{~F}$ & $\mathrm{~F}$ & 0 \\
\hline SD & June 7 & 0 & $\mathrm{~F}$ & F & 0 \\
\hline Leaf removal & June 9-10 & $\mathrm{x}$ & 0 & $\mathrm{x}$ & 0 \\
\hline MB; WS; CP & June 12 & 0 & $\mathrm{~F}$ & $\mathrm{~F}$ & 0 \\
\hline SD & June 26 & 0 & $\mathrm{~F}$ & $\mathrm{~F}$ & 0 \\
\hline SD & July 10 & 0 & $\mathrm{~F}$ & $\mathrm{~F}$ & 0 \\
\hline \multicolumn{6}{|l|}{ Madera 1990} \\
\hline SD ( 3 applications) & March/April & $\mathbf{F}$ & F & $\mathrm{F}$ & $\mathbf{F}$ \\
\hline FM $(0.19 \mathrm{lb}) ;$ WS $(2.0 \mathrm{lb})$ & May 10 & 0 & $\mathrm{~F}$ & $\mathbf{F}$ & 0 \\
\hline Leaf removal & May 21 & $\mathrm{x}$ & 0 & $x$ & 0 \\
\hline $\mathrm{FM}(0.31 \mathrm{lb}) ;$ WS $(4.0 \mathrm{lb})$ & May 25 & $\mathrm{~F}$ & $\mathrm{~F}$ & $\mathrm{~F}$ & $\mathrm{~F}$ \\
\hline FM $(0.31 \mathrm{lb}) ;$ WS $(4.0 \mathrm{lb})$ & June 4 & $\mathrm{~F}$ & $\mathrm{~F}$ & F & $\mathrm{F}$ \\
\hline MB (0.31 lb); WS (2.0 lb) & July 9 & $\mathrm{~F}$ & $\mathrm{~F}$ & $\mathrm{~F}$ & $\mathrm{~F}$ \\
\hline \multicolumn{6}{|l|}{ Madera 1991} \\
\hline FM $(0.13 \mathrm{lb}) ;$ WS $(2.0 \mathrm{lb})$ & May 17 & $\mathrm{~F}$ & $\mathrm{~F}$ & $\mathrm{~F}$ & $\mathrm{~F}$ \\
\hline Leaf removal & May 30 & $\mathrm{x}$ & 0 & $\mathrm{x}$ & 0 \\
\hline $\begin{array}{l}\text { FM }(0.13 \text { or } 0.25 \mathrm{lb}) \\
\text { WS }(1.25 \text { or } 2.5 \mathrm{lb})\end{array}$ & May 31 & $+\S$ & + & + & + \\
\hline $\mathrm{FM}(0.16$ or $0.31 \mathrm{lb})$ & June 20 & + & + & + & + \\
\hline
\end{tabular}

"No subsequent fungicide applications unless noted.

†Full fungicides.

$\ddagger F=$ fungicide(s) or $X=$ leaf removal applied; $0=$ no fungicide(s) applied.

$\S$ Treatments including leaf removal received lower dosage; treatments not including leaf removal received higher dosage.

Madera 1990. This field experiment involved a Carignane vineyard with a history of severe powdery mildew problems. Cultural conditions and plot design were similar to the 1989 Madera experiment, except that rows were oriented in an east-west direction. Disease ratings were taken at the September 5 harvest.

Lodi 1990. An experiment similar to the 1990 Madera test was conducted in a Chardonnay vineyard, with rows oriented in a north-south direction. To protect against berry darkening and sunburn, leaves were not removed from the west side of vines. The control vines received no fungicides over the course of the season. Disease parameters were evaluated prior to harvest on September 4. 
Madera 1991. This experiment was located in the same vineyard as the 1989 trial and was similarly designed, except that three fungicide rates were used $-100 \%, 50 \%$ and $0 \%$ of the grower's standard practice. Leaves were removed only from the southeast side of vines to protect against sunburn. Powdery mildew and yield data were taken on October 3.

Leaf removal is done after bloom, so fungicide sprays must be initiated several weeks before bloom to protect the vines against powdery mildew. Vines selected for leaf removal received early season fungicide sprays according to the grower's standard. After this initial treatment, these experimental vines received fungicide applications only if observations indicated complete loss of usable grape yield without them (table 1). Each cluster on the experimental vines was evaluated for powdery mildew with disease ratings expressed as percent incidence (clusters with any amount of mildew) and severity (amount of each cluster with mildew) at all locations.

\section{Estimate of spray coverage}

We used indicator cards ( 2 inches by 3 inches) made of moisture-sensitive paper to compare fungicide spray coverage in leaf removal treatments in the 1991 Madera and 1990 Lodi experiments. The cards were attached to shoots near fruit clusters in the interior of one grapevine canopy per replicate. Following fungicide spray applications (handgun-applied at Madera and commercial speed sprayer-applied at Lodi), coverage of surface area was estimated by placing a cardboard template with 10 randomly punched holes (0.3 inch diameter) over each card. Percent coverage beneath each hole was visually estimated, and data were composited and subjected to analysis of variance and mean separation tests.

\section{Powdery mildew control}

Madera 1989. Both leaf removal and the grower's fungicide program were found to be highly significant in reducing the incidence and severity of powdery mildew at both evaluation
TABLE 2. Influence of leaf removal and fungicide sprays on incidence and severity of powdery mildew (Uncinula necator) and on usable yield of wine grapes in the San Joaquin Valley

\begin{tabular}{|c|c|c|c|}
\hline $\begin{array}{l}\text { Year, location, } \\
\text { variety, treatment }\end{array}$ & Incidence* & Severityt & Yield \\
\hline 1989, Madera & $\%$ & $\%$ & $\mathrm{~kg} /$ vine \\
\hline \multicolumn{4}{|l|}{ Carignane } \\
\hline Leaf removal\$ & 17.7 & 11.0 & 21.5 \\
\hline Grower's standard practice & 4.2 & 9.8 & 24.6 \\
\hline Leaf removal + Grower's practice & 2.1 & 20.0 & 21.7 \\
\hline Control & 70.8 & 31.0 & 23.3 \\
\hline \multicolumn{4}{|l|}{ ANOVA } \\
\hline Leaf removal & 0.001 & 0.05 & 0.05 \\
\hline Grower's standard practice & 0.001 & 0.001 & 0.01 \\
\hline Leaf removal + Grower's practice & 0.001 & 0.05 & 0.05 \\
\hline \multicolumn{4}{|l|}{ 1989. Lodi } \\
\hline \multicolumn{4}{|l|}{ Carignane } \\
\hline Leaf removal & 57.3 & 30.1 & 29.1 \\
\hline Grower's standard practice & 7.3 & 5.3 & 30.1 \\
\hline Leaf removal + Grower's practice & 4.2 & 1.9 & 35.2 \\
\hline Control & 66.7 & 34.5 & 33.7 \\
\hline \multicolumn{4}{|l|}{ ANOVA } \\
\hline Leaf removal & ns $\S$ & ns & ns \\
\hline Grower's standard practice & 0.001 & 0.001 & ns \\
\hline Leaf removal + Grower's practice & ns & ns & 0.01 \\
\hline
\end{tabular}

1990. Madera

Carignane

Leaf removal

Grower's standard practice

Leaf removal + Grower's practice

Control

57.5

21.3

15.0

79.4

56.8

18.7

14.2

69.7

17.4

ANOVA

Leaf removal

Grower's standard practice

Leaf removal + Grower's practice

ns

0.01

ns

ns

0.0

ns

ns

ns

1990. Lodi

Chardonnay

Leaf removal

Grower's standard practice

Leaf removal + Grower's practice

Control

56.6

7.6

7.8

41.4

23.0

6.9

5.8

20.1

12.2

ANOVA

Leaf removal

Grower's standard practice

Leaf removal + Grower's practice

ns

0.0

ns

0.0

0.01

ns

ns

ns

\section{Madera}

\section{Carignane}

Leaf removal + full fungicides

Leaf removal + no fungicides

No leaf removal + full fungicides

No leaf removal + half fungicides

No leaf removal + no fungicides

ANOVA

Leaf removal

Fungicides

Leaf removal + fungicides
Leaf removal + half fungicides

\begin{tabular}{lll}
33.1 & 10.4 & 22.0 \\
42.5 & 5.4 & 23.5 \\
87.5 & 42.6 & 19.5 \\
50.6 & 20.0 & 24.6 \\
56.9 & 22.3 & 25.6 \\
79.459 .8 & 26.0 & \\
& & \\
ns & & \\
$\quad 0.0001$ & 0.01 & 0.005 \\
ns & 0.0001 & ns \\
\hline
\end{tabular}

-Percent clusters with mildew. ANOVA done with arcsin-transformed values of data. †Percent mildew per cluster. ANOVA done with arcsin-transformed values of data. †Leaf removal: no subsequent fungicide applications unless noted; Grower's standard practice: full fungicides.

$\S \mathrm{ns}=$ not significant. 
times. Since results were similar, only data from the September 1 rating are reported here (table 2 ). Leaf removal without subsequent fungicide sprays reduced the incidence of powdery mildew by $75 \%$, and severity by $65 \%$, when compared to control vines. The full fungicide program was more successful, reducing the incidence of disease by $94 \%$ and severity by $68 \%$. Combining leaf removal with a full fungicide spray program produced inconsistent results; while the incidence of powdery mildew was further reduced by combining the treatments, the severity of the disease was greater than when either treatment was used alone. Grape yield was reduced 6 to $7 \%$ by leaf removal.

Lodi 1989. Leaf removal on the head-trained Carignane vines did not result in significantly reduced powdery mildew disease ratings (table 2), as shown in data from the October 5 rating. The grower's full fungicide program was successful in reducing incidence and severity of powdery mildew by $89 \%$ and $85 \%$, respectively. Neither treatment alone significantly affected yield; however, the combined treatment of leaf removal and full fungicides resulted in a 17 to $21 \%$ increase of yield over either treatment alone.

Madera 1990. Leaf removal did not have a significant effect on reducing the incidence or severity of powdery mildew in the Carignane vineyard with a history of more mildew damage. The grower's full fungicide program, alone or with leaf removal, was found to be highly significant in reducing the incidence and severity by 73 to $81 \%$, and 73 to $80 \%$, respectively. We found no significant interaction between leaf removal and fungicides. Fungicides applied by the grower significantly contributed to increased grape yield ( 36 to $96 \%$ ).

Lodi 1990. Leaf removal did not significantly affect incidence or severity of powdery mildew in the Chardonnay vineyard (table 2). The full fungicide program was highly successful in reducing severity and incidence, and increasing usable yield. Combining leaf removal with fungicide applications did not significantly affect mildew control.
Madera 1991. Leaf removal alone reduced the severity of powdery mildew, but incidence was not affected (table 2). Fungicide treatments were highly successful in reducing both incidence and severity of the disease. Leaf removal significantly reduced usable grape yields by 8 to $25 \%$, presumably because some small clusters were damaged or destroyed by field workers in late May when the treatment was imposed.

\section{Spray coverage}

Percent spray coverage at the Madera site was evaluated three times during the season, while coverage at Lodi was evaluated only once, shortly after leaf removal. Results from both sites showed coverage was significantly better throughout the season in plots subjected to leaf removal (table 3 ).

\section{Conclusions}

Leaf removal has been successfully employed to reduce the impact of Botrytis bunch rot, the summer bunch rot complex, and insects including leafhoppers and omnivorous leaf roller, and to increase the quality of wine grapes in California. The results of this study, coupled with results of Napa Valley studies, indicate that leaf removal can help reduce the incidence and severity of powdery mildew. Since leaf removal is not normally

TABLE 3. Estimated coverage of moisturesensitive paper cards by sprays applied to wine grape vines in the San Joaquin Valley, 1991

\begin{tabular}{|c|c|c|c|}
\hline \multirow{2}{*}{$\begin{array}{l}\text { Location, variety, } \\
\text { method, treatment } \\
\text { Madera }\end{array}$} & \multicolumn{3}{|c|}{$\begin{array}{c}\text { Date of spray } \\
\text { application and } \\
\text { percent coverage }\end{array}$} \\
\hline & & & \\
\hline $\begin{array}{l}\text { Carignane } \\
\text { Hand gun }\end{array}$ & May 31 & Jun 20 & Oct 7 \\
\hline $\begin{array}{l}\text { Leaf removal (2-side) } \\
\text { Leaf removal (1-side) } \\
\text { Control }\end{array}$ & $\begin{array}{l}90 \mathrm{a}^{*} \\
70 \mathrm{a} \\
36 \mathrm{~b}\end{array}$ & $\begin{array}{l}87 \mathrm{a} \\
54 \mathrm{~b} \\
34 \mathrm{c}\end{array}$ & $\begin{array}{l}73 a \\
74 a \\
44 b\end{array}$ \\
\hline \multicolumn{4}{|l|}{ Lodi } \\
\hline \multicolumn{3}{|l|}{ Chardonnay } & \\
\hline $\begin{array}{l}\text { Leaf removal (1-side) } \\
\text { Control }\end{array}$ & $\begin{array}{l}94 \dagger \\
83\end{array}$ & & \\
\hline
\end{tabular}

-Values followed by different letters are different ( $P$ $\leq 0.05$ ) according to Duncan's multiple range test. †Values are different $(P \leq 0.05)$ according to Student's t-test.

All data analyzed using arcsin-transformed values. done until the late-bloom stage of grape development, several weeks after the need for protection of foliage against powdery mildew begins, it does not reduce the need for earlyseason control measures. Although leaf removal alone may not provide predictable control of powdery mildew, particularly on highly susceptible grape varieties, benefit to late season powdery mildew management may accrue when it is practical. This is of economic importance to growers who use leaf removal for other pest management or viticultural reasons.

As a previous study in the San Joaquin Valley has already demonstrated, leaf removal had no consistent effect on usable grape yield. However, significantly reduced yields were associated with leaf removal in two of the five field experiments. Thus, it must be emphasized that inadvertent damage to small clusters by inexperienced workers imposing the treatment may add to the overall cost of the practice.

This study also demonstrated that spray coverage within the vine canopy is significantly increased by removing leaves, although significant treatment interactions between leaf removal and fungicide application were found only in one of the five field experiments. Nevertheless, these findings add to the breadth of knowledge and extent of potential economic benefits for California wine grape growers, particularly when growers couple leaf removal with fungicide and/or insecticide spray regimes that depend upon direct contact with target organisms in clusters for activity .

J.J. Stapleton is IPM Specialist, UC Statewide IPM Project, Kearney Agricultural Center, Parlier; G.M. Leavitt and P.S. Verdegaal are Viticulture Farm Advisors, Madera and San Joaquin counties, respectively.

The authors thank R. Duncan, D. Hubert, T. Martin-Duvall, D. Modrell, J. Valenti and T. Viss for technical assistance; and growers P. Cappelluti, P. Hale, Kautz Vineyards and J. Lilles for cooperation. The research was partially sponsored by grants from the UC Statewide IPM Project. 